\title{
Opinion
}

\section{The Reframing of Advance Care Planning: How Coronavirus Disease 2019 has Encouraged Us to Reflect More on our Values}

\author{
Andrew Saunderson, RSW \\ 504-3292 Production Way, Burnaby, BCV5A 4R4, Canada \\ "Corresponding author \\ Andrew Saunderson, RSW \\ 504-3292 Production Way, Burnaby, BCV5A 4R4, Canada; E-mail: Andrew.Saunderson@fraserhealth.ca
}

Article information

Received: August 18 ${ }^{\text {th }}, 2020$; Accepted: September $7^{\text {th }}, 2020$; Published: September 10 ${ }^{\text {th }}, 2020$

\section{Cite this article}

Saunderson A. The reframing of advance care planning: How coronavirus disease 2019 has encouraged us to reflect more on our values. Palliat Med Hosp Care Open J. 2020; 6(I): 14. doi: 10.17140/PMHCOJ-6-136

\begin{abstract}
Cor oronavirus disease 2019 (COVID-19) has contributed to some unintended, yet valuable, reframing of advance care planning (ACP). Rather than perceiving ACP as merely being about death and dying, many healthcare providers and community members now acknowledge the need to plan in advance for healthcare decisions, especially if we are unable to communicate and consent for ourselves. Rather than perceiving ACP conversations as "difficult conversations", many healthcare providers and community members now acknowledge them as important and essential conversations. And rather than perceiving that ACP is primarily for the elderly or seriously ill, many healthcare providers and community members now acknowledge that we are all mortal and could unexpectedly become sick or injured; therefore, ACP is of value for all.
\end{abstract}

As Sudore et $\mathrm{al}^{1}$ concluded, "Advance care planning is a process that supports adults at any age or stage of health". And the primary goal of ACP is "to help ensure that people receive medical care that is consistent with their values, goals and preferences". ${ }^{1}$ Due to discomfort with uncertainty and craving to feel some sense of control, particularly during times of crisis, many people presume that ACP is about considering and choosing specific medical treatments in advance. And yet, at the core of ACP is in fact values. Our values dictate most, if not all, of our choices and actions. Whether conscious or unconscious, our values influence what we wear, who we spend time with, what we eat, where we travel, what we listen to and watch, and what activities we engage in or events we attend. Similarly, our values directly inform our healthcare decision-making. Whether someone chooses to pursue a surgery, a new medication, or a feeding tube, those decisions are not merely made by considering the medical risks and benefits, but equally, if not more so, they are chosen because of how someone wishes to live as a result of the medical intervention. ACP is not about how we want to die, but rather how we want to live.
Reflecting on and naming our values can often be challenging as values seem far too abstract to identify at times. However, medical professionals who actively practice ACP have consistently observed how a few simple questions can help easily discover and record a person's values. These include asking: What does a good day look like? What brings your life meaning and purpose? And what brings you joy? These questions often turn into an unexpected, yet valuable, joy list that highlights the things, people, places, and beliefs that are most important to us and bring meaning and happiness into our lives. A joy list whether short or long, is a gift to patients, healthcare providers, and substitute decision makers/ health proxies, as it helps to ensure that the healthcare decisions made align with who you are and how you want to live. Joy lists and the prioritizing of your values, reminds the healthcare system that quality of life is equally important as quantity of life.

While COVID-19 has turned so much of our world upside down, it has simultaneously provided a unique opportunity for all of us to reflect a little more on our values, as we more intentionally consider what brings our life meaning and what brings us joy. Taking time to reflect on, record, and share our values is an imperative part of ACP. During a time when so many things feel uncertain and out of our control, ACP provides an invaluable sense of control over our health and future.

\section{REFERENCES |}

1. Sudore RL, Lum HD, You JY, Hanson LC, Meier DE, Pantilat SZ, et al. Defining Advance care planning for adults: A consensus definition from a multidisciplinary Delphi panel. J Pain Symptom Manage. 2017; 53(5): 821-832.e1. doi: 10.1016/j.jpainsymman.2016.12.331 